Check for updates

Cite this: Phys. Chem. Chem. Phys., 2022, 24, 1666

Received 19th October 2021, Accepted 18th December 2021 DOI: $10.1039 / d 1 c p 04779 e$

rsc.li/pccp

\title{
Magnetically induced ring currents in metallocenothiaporphyrins $\dagger$
}

\author{
Rashid R. Valiev, ${ }^{a b}$ Theo Kurten, $^{b}$ Lenara I. Valiulina, ${ }^{a}$ Sergey Yu. Ketkov, (D) ${ }^{c}$ \\ Viktor N. Cherepanov, ${ }^{a}$ Maria Dimitrova (D) ${ }^{b}$ and Dage Sundholm (D)*b
}

\begin{abstract}
The magnetically induced current-density susceptibility tensor (CDT) of the lowest singlet and triplet states of the metallocenothiaporphyrins, where the metal is $\mathrm{V}, \mathrm{Cr}, \mathrm{Mn}, \mathrm{Fe}, \mathrm{Co}, \mathrm{Ni}, \mathrm{Mo}, \mathrm{Tc}, \mathrm{Ru}$, or Rh, have been studied with the gauge-including magnetically induced currents (GIMIC) method. The compounds containing V, Mn, Co, Tc or Rh were studied as cations because the neutral molecules have an odd number of electrons. The calculations show that the aromatic nature of most of the studied molecules follows the Hückel and Baird rules of aromaticity. CDT calculations on the high-spin states of the neutral metallocenothiaporphyrins with $\mathrm{V}, \mathrm{Mn}, \mathrm{Co}, \mathrm{Tc}$ or Rh also shows that these molecules follow a unified extended Hückel and Baird aromaticity orbital-count rule stating that molecules with an odd number of occupied conjugated valence orbitals are aromatic, whereas molecules with an even number of occupied conjugated orbitals are antiaromatic.
\end{abstract}

\section{Introduction}

Classical metallocenes are organic sandwich compounds formed by two cyclopentadienyl rings and a transition metal (M). The general formula of metallocene structures is $\left(\eta^{5}-\mathrm{C}_{5} \mathrm{H}_{5}\right)_{2} \mathrm{M}$ where the metal ion in the oxidation state $2+$ is located between two parallel cyclopentadienyl anions at equal or nearly equal distances from all carbon atoms of the two cyclopentadienyl $\left(\left(\mathrm{C}_{5} \mathrm{H}_{5}\right)_{2}\right)$ rings. The metal in the $3 \mathrm{~d}$ and $4 \mathrm{~d}$ metallocenes is bound to the ligands via covalent chemical bonds except for manganocene exhibiting ionic bonding. ${ }^{1}$ Vanadocene and chromocene have partly ionic metal-ligand bonds. ${ }^{2}$ The covalent contribution to the $\mathrm{M}-\mathrm{C}_{5} \mathrm{H}_{5}$ bonds is provided mainly by the overlap between the $3 \mathrm{~d}$ orbitals of the metal and the $\pi$-orbitals of the $\mathrm{C}_{5} \mathrm{H}_{5}$ ring. ${ }^{3}$

Ferrocene, which is the first discovered metallocene, was synthesized independently in 1951 by the groups led by Pauson, and Miller. ${ }^{4,5}$ The intriguing ferrocene sandwich structure was suggested by the groups of Woodward, Wilkinson ${ }^{6}$ and Fischer. ${ }^{7}$ The discovery of ferrocene inspired subsequent synthesis of new similar metal complexes. Already by 1954, metallocenes of most of the d elements had been synthesized

\footnotetext{
${ }^{a}$ Department of Optics and Spectroscopy, Tomsk State University, Tomsk, 634050, Russia

${ }^{b}$ Department of Chemistry, Faculty of Science, University of Helsinki, FIN-00014, Helsinki, Finland. E-mail: sundholm@chem.helsinki.fi

${ }^{c}$ Laboratory of Structures of Organometallic and Coordination Compounds,

G. A. Razuvaev Institute of Organometallic Chemistry RAS, 49 Tropinin St., Nizhny Novgorod 603950, Russia

$\dagger$ Electronic supplementary information (ESI) available. See DOI: 10.1039/ d1cp04779e
}

and characterized. However, ferrocene is the most stable of all known metallocenes.

The stability of ferrocene is explained by the so-called 18-electron rule. According to this rule, the most stable structure is obtained when the sum of the valence electrons of a transition metal and the ligand electrons participating in bonding is 18 . Only the metallocenes with a metal from group VIII can be neutral 18-electron complexes. Metals from other groups form less stable, reactive complexes, and do not always lead to the formation of an ideal sandwich structure. ${ }^{1}$ For first-row transition metals, the stability of the metallocenes decreases in the following order: $\mathrm{Fe}>\mathrm{Ni}>\mathrm{Co}>\mathrm{V} \gg \mathrm{Cr}>\mathrm{Ti}^{2}{ }^{2}$ Due to their unique chemical properties, metallocenes are widely used in various applications..$^{8-15}$

The reactivity of ferrocene resembles that of benzene. It is, therefore, referred to as a non-benzoic cylindrically aromatic system with $4 n$ conjugated electrons. ${ }^{16,17}$ Ferrocene has been the subject of many studies. ${ }^{18-21}$ The conjugation transmitted by the $\mathrm{d}$ electrons of ferrocene and ruthenocene has been studied by incorporating it into a porphyrinoid compound. ${ }^{22,23}$ Porphyrins and their derivatives are widely used in various fields due to their rigid molecular structure and strong light absorption in the visible region. ${ }^{24-30}$

The wide variety of porphyrin compounds and their unique electronic structure enable studies of the relationship between aromaticity and physicochemical properties. The aromatic character influences the optical properties of porphyrins such as light absorption, excitedstate lifetimes, fluorescence quantum yields, and nonlinear optical properties including two-photon absorption. ${ }^{31,32}$ 
Since metallocenes and porphyrins are important molecules in many contexts, the combination of the two compounds by incorporating various metallocenes into the porphyrin macrocycle may result in molecules with intriguing properties. ${ }^{22,23}$ The number of $\mathrm{d}$ electrons contributing to the electron delocalization determines the aromatic character and can be adjusted by choosing the metal and the number of the inner hydrogens connected to the pyrrole rings. The current-density flux and the ring current passing the metal of the ferrocene moiety could not be elucidated neither spectroscopically nor computationally ${ }^{22}$ because the current-density flux is very complicated with a helical flux at the ferrocene as shown in this study.

Aromaticity can be assessed using a range of criteria, among which is the ring-current criterion employed in this study. An external magnetic field induces a diatropic ring current in aromatic molecular rings, whereas in antiaromatic molecules the ring current flows in the non-classical, i.e., the paratropic direction. The degree of aromaticity can be judged by determining the magnitude of the induced ring-current strengths, ${ }^{33}$ which are obtained by integrating the current density flux using the GIMIC program. Detailed information about the GIMIC program and its capabilities can be found in recent reviews. $^{34-36}$

The aim of this work is to investigate the aromaticity and electronic delocalization in porphyrinoid rings with incorporated metallocenes. We have studied how the current density is affected when reducing the molecule by adding two inner hydrogen atoms to the porphyrinoid. We have formulated a generalization of the Hückel and Baird aromaticity rules, which can be extended to systems with more than two open shells.

\section{Molecular structures}

We denote the metallocenothiaporphyrin and the dihydrometallocenothiaporphyrin compounds $\left(\mathrm{C}_{5} \mathrm{H}_{5}\right)_{2} \mathrm{MP}$ and $\mathrm{H}_{2}-\left(\mathrm{C}_{5} \mathrm{H}_{5}\right)_{2} \mathrm{MP}$, respectively. The molecular structures of $\left(\mathrm{C}_{5} \mathrm{H}_{5}\right)_{2} \mathrm{MP}$ and $\mathrm{H}_{2}-\left(\mathrm{C}_{5} \mathrm{H}_{5}\right)_{2} \mathrm{MP}$ are shown in Fig. 1. We have studied $\left(\mathrm{C}_{5} \mathrm{H}_{5}\right)_{2} \mathrm{MP}$ and $\mathrm{H}_{2}-\left(\mathrm{C}_{5} \mathrm{H}_{5}\right)_{2} \mathrm{MP}$ compounds, where $\mathrm{M}$ is a $3 \mathrm{~d}$ transition metal from $\mathrm{Sc}$ to $\mathrm{Zn}$ or a $4 \mathrm{~d}$ transition metal from $\mathrm{Y}$ to $\mathrm{Cd}$. However, many of the studied molecules were unstable at the employed level of theory and were not studied further. We have investigated the lowest singlet and triplet states of the neutral $\mathrm{M}=\mathrm{Cr}$, $\mathrm{Fe}, \mathrm{Ni}, \mathrm{Mo}$, and Ru compounds as well as the lowest singlet and triplet states of the $\mathrm{M}=\mathrm{Co}, \mathrm{Mn}, \mathrm{V}, \mathrm{Tc}$, and $\mathrm{Rh}$ containing

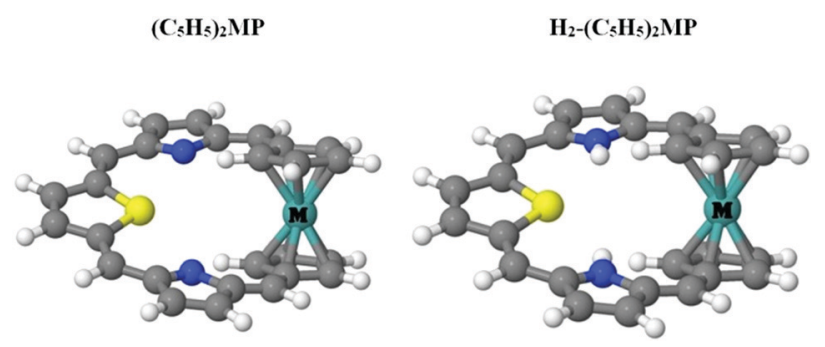

Fig. 1 The molecular structures of the studied metallocenothiaporphyrins, where $\mathrm{M}=\mathrm{V}, \mathrm{Cr}, \mathrm{Mn}, \mathrm{Fe}, \mathrm{Co}, \mathrm{Ni}, \mathrm{Mo}, \mathrm{Tc}, \mathrm{Ru}$ and Rh.
$\left(\mathrm{C}_{5} \mathrm{H}_{5}\right)_{2} \mathrm{MP}^{+}$and $\mathrm{H}_{2}-\left(\mathrm{C}_{5} \mathrm{H}_{5}\right)_{2} \mathrm{MP}^{+}$cations. We have also studied the sextet ground state of the neutral $\mathrm{Mn}$ and Tc compounds as well as the quartet ground state of the neutral vanadium compound.

The porphyrin macrocycle consists of two pyrrole rings and one thiophene ring which are connected at their $\alpha$-carbon atoms via methine bridges. The metallocene is linked via methine bridges to the two pyrrole rings of the thiaporphyrin. The pyrrole rings of $\mathrm{H}_{2}-\left(\mathrm{C}_{5} \mathrm{H}_{5}\right)_{2} \mathrm{MP}$ have inner hydrogen atoms increasing the formal number of $\pi$ electrons by two compared to $\left(\mathrm{C}_{5} \mathrm{H}_{5}\right)_{2} \mathrm{MP}$.

\section{Computational methods}

The molecular structures were optimized at the density functional theory (DFT) level using the Becke, Lee, Yang, Parr (B3LYP) functional $^{37,38}$ and the Karlsruhe def2-TZVP ${ }^{39}$ basis set. The Cartesian coordinates of the molecular structures are given in the ESI. $\dagger$ The average bond lengths (in $\AA$ ) between the metal and the carbon atoms of the cyclopentadienyl rings are also reported in the ESI. $\dagger$ Calculations of the vibrational frequencies showed that the optimized molecular structures are minima on the potential energy surface.

The magnetically induced current density susceptibility tensors (CDT) were calculated using the GIMIC method, ${ }^{33}$ which uses the Cartesian coordinates of the atoms, basis-set information, and density matrices as input data. The first-order magnetically perturbed density matrices are obtained by performing nuclear magnetic resonance (NMR) shielding calculations, while the unperturbed density matrix is obtained in self-consistent field (SCF) DFT calculations. The density matrices were computed at the B3LYP/def2-TZVP level using Gaussian 16. ${ }^{40}$ A tool that converts the Gaussian output into appropriate input format for GIMIC was employed. ${ }^{33,41}$

The ring-current strengths ( $I$ in $\mathrm{nA} \mathrm{T}^{-1}$ ) were obtained by integrating the current-density flux passing through a plane placed perpendicularly to the molecular structure crossing a given chemical bond. ${ }^{35}$ The sign and magnitude of the ringcurrent strengths are used for determining the character and degree of aromaticity. Negative ring-current strengths indicate antiaromatic character, that is, the paratropic ring current dominates, while positive ring-current strengths suggest that the molecule is aromatic with a dominating diatropic ring current. $^{33-35}$ Previous current-density studies showed that DFT calculations using the B3LYP functional ${ }^{42-44}$ yield accurate ring-current strengths and degree of aromaticity for aromatic and weakly antiaromatic molecules. However, B3LYP calculations overestimate the strength of the paratropic ring current of strongly antiaromatic molecules. ${ }^{45}$ We have studied the CDT, ring-current strengths, and aromatic pathways of the lowest singlet and triplet states of $\left(\mathrm{C}_{5} \mathrm{H}_{5}\right)_{2} \mathrm{VP}^{+},\left(\mathrm{C}_{5} \mathrm{H}_{5}\right)_{2} \mathrm{CrP},\left(\mathrm{C}_{5} \mathrm{H}_{5}\right)_{2} \mathrm{MnP}^{+},\left(\mathrm{C}_{5} \mathrm{H}_{5}\right)_{2} \mathrm{FeP}$, $\left(\mathrm{C}_{5} \mathrm{H}_{5}\right)_{2} \mathrm{CoP}^{+},\left(\mathrm{C}_{5} \mathrm{H}_{5}\right)_{2} \mathrm{NiP},\left(\mathrm{C}_{5} \mathrm{H}_{5}\right)_{2} \mathrm{MoP},\left(\mathrm{C}_{5} \mathrm{H}_{5}\right)_{2} \mathrm{TcP}^{+},\left(\mathrm{C}_{5} \mathrm{H}_{5}\right)_{2} \mathrm{RuP}$, and $\left(\mathrm{C}_{5} \mathrm{H}_{5}\right)_{2} \mathrm{RhP}^{+}$as well as for the quartet state of the neutral $\left(\mathrm{C}_{5} \mathrm{H}_{5}\right)_{2} \mathrm{VP}$ and the sextet state of the neutral $\left(\mathrm{C}_{5} \mathrm{H}_{5}\right)_{2} \mathrm{MnP}$ and $\left(\mathrm{C}_{5} \mathrm{H}_{5}\right)_{2} \mathrm{TcP}$. 


\section{Results and discussion}

\section{Aromaticity rules}

The total number of electrons participating in the bond conjugation can be determined by accounting for the number of electrons in the porphyrinoid part of the conjugation pathway, the valence electrons of the metal and the $\pi$ electrons of the $\mathrm{C}_{5} \mathrm{H}_{5}$ rings. The cyclopentadienyl anions have $12 \pi$ electrons of which two are energetically low-lying. The number of electrons contributing to the conjugation pathway of the other metallocenes originating from the metal is equal to the number of valence d electrons of the metal. $\mathrm{Fe}^{2+}$ has $6 \mathrm{~d}$ electrons. Thus, the ferrocene unit provides 16 electrons to the bond conjugation. For $\left(\mathrm{C}_{5} \mathrm{H}_{5}\right)_{2} \mathrm{MP}$, the porphyrinoid part contributes with $20 \pi$ electrons. Combined with the 16 valence electrons in the ferrocene moiety, this yields 36 electrons in the conjugation pathway of $\left(\mathrm{C}_{5} \mathrm{H}_{5}\right)_{2} \mathrm{FeP}$. Given that the number of electrons fulfills Hückel's rule for antiaromaticity, the singlet state of $\left(\mathrm{C}_{5} \mathrm{H}_{5}\right)_{2} \mathrm{FeP}$ is expected to be antiaromatic. $\mathrm{H}_{2}-\left(\mathrm{C}_{5} \mathrm{H}_{5}\right)_{2} \mathrm{FeP}$ has 38 conjugated electrons since the porphyrinoid part contributes with $22 \pi$ electrons implying that the singlet state of $\mathrm{H}_{2}-\left(\mathrm{C}_{5} \mathrm{H}_{5}\right)_{2} \mathrm{FeP}$ is expected to be aromatic. ${ }^{46-48}$ Similarily, the triplet states of $\left(\mathrm{C}_{5} \mathrm{H}_{5}\right)_{2} \mathrm{FeP}$ and $\mathrm{H}_{2}-\left(\mathrm{C}_{5} \mathrm{H}_{5}\right)_{2} \mathrm{FeP}$ are expected to be aromatic and antiaromatic, respectively, according to Baird's aromaticity rule. ${ }^{48-50}$

The same aromaticity rules can be applied to the isoelectronic $\left(\mathrm{C}_{5} \mathrm{H}_{5}\right)_{2} \mathrm{CoP}^{+}$and $\mathrm{H}_{2}-\left(\mathrm{C}_{5} \mathrm{H}_{5}\right)_{2} \mathrm{CoP}^{+}$cations as well as to the corresponding compounds containing the $4 \mathrm{~d}$ metals: $\left(\mathrm{C}_{5} \mathrm{H}_{5}\right)_{2} \mathrm{RuP}$, $\left(\mathrm{C}_{5} \mathrm{H}_{5}\right)_{2} \mathrm{RhP}^{+}, \mathrm{H}_{2}-\left(\mathrm{C}_{5} \mathrm{H}_{5}\right)_{2} \mathrm{RuP}$ and $\mathrm{H}_{2}-\left(\mathrm{C}_{5} \mathrm{H}_{5}\right)_{2} \mathrm{RhP}^{+}$. The vanadium complexes $\left(\mathrm{C}_{5} \mathrm{H}_{5}\right)_{2} \mathrm{VP}^{+}$and $\mathrm{H}_{2}-\left(\mathrm{C}_{5} \mathrm{H}_{5}\right)_{2} \mathrm{VP}^{+}$have four electrons less than the $[\mathrm{Fe}]$-cenothiaporphyrins and are expected to have the same aromatic character as the [Fe]-cenothiaporphyrins.

Reversed aromaticity rules are expected for the corresponding Ni compounds with two electrons more than the Fe containing compounds. The $\mathrm{Cr}$ and Mo containing compounds with two valence electrons less than $[\mathrm{Fe}]$-cenothiaporphyrin and the valence isoelectronic $\mathrm{Mn}^{+}$and $\mathrm{Tc}^{+}$cations are also expected to have reverse aromaticity compared to the corresponding [Fe]cenothiaporphyrin.

\section{$\left(\mathrm{C}_{5} \mathrm{H}_{5}\right)_{2} \mathrm{FeP}$ and $\mathrm{H}_{2}-\left(\mathrm{C}_{5} \mathrm{H}_{5}\right)_{2} \mathrm{FeP}$ and isoelectronic compounds of group VIII}

Calculations of the magnetically induced ring current (MIRC) of the singlet state of $\left(\mathrm{C}_{5} \mathrm{H}_{5}\right)_{2} \mathrm{FeP}$ yield a ring-current strength of $-10.4 \mathrm{nA} \mathrm{T}^{-1}$ when the external magnetic field is nearly perpendicular to the porphyrinoid ring, whereas $\mathrm{H}_{2}-\left(\mathrm{C}_{5} \mathrm{H}_{5}\right)_{2} \mathrm{FeP}$ with two inner hydrogens is aromatic sustaining a MIRC of $13.8 \mathrm{nA} \mathrm{T}^{-1}$, which is comparable to the strength of the MIRC of benzene of $12 \mathrm{nA} \mathrm{T}^{-1} \cdot{ }^{51}$ The triplet state of $\left(\mathrm{C}_{5} \mathrm{H}_{5}\right)_{2} \mathrm{FeP}$ is calculated to be $12.0 \mathrm{kcal} \mathrm{mol}^{-1}$ above the singlet state and the triplet state of $\mathrm{H}_{2}-\left(\mathrm{C}_{5} \mathrm{H}_{5}\right)_{2} \mathrm{FeP}$ is analogously $17.8 \mathrm{kcal} \mathrm{mol}^{-1}$ above the singlet state. The calculated ring-current strength of the triplet state of $\left(\mathrm{C}_{5} \mathrm{H}_{5}\right)_{2} \mathrm{FeP}$ is $6.2 \mathrm{nA} \mathrm{T}^{-1}$ and the triplet state of $\mathrm{H}_{2}-\left(\mathrm{C}_{5} \mathrm{H}_{5}\right)_{2} \mathrm{FeP}$ sustains a ring current of $-9.0 \mathrm{nA} \mathrm{T}{ }^{-1}$. Thus, the aromatic character of the studied states of the [Fe]cenothiaporphyrins follows the Hückel rule of aromaticity,
Table 1 The strengths (in $\mathrm{nA} \mathrm{T}^{-1}$ ) of the magnetically induced ring currents of the studied $\left(\mathrm{C}_{5} \mathrm{H}_{5}\right)_{2} \mathrm{MP}$ and $\mathrm{H}_{2}-\left(\mathrm{C}_{5} \mathrm{H}_{5}\right)_{2} \mathrm{MP}$ molecules. Negative ring-current strengths mean that the molecule is antiaromatic, while aromatic molecules have positive ring-current strengths. When the absolute value of the ring-current strength is smaller than $3 \mathrm{nA} \mathrm{T} \mathrm{T}^{-1}$, the molecule can be considered non-aromatic. Diatropic MIRC are given in blue and paratropic in red. Very weak MIRC strengths indicating nonaromaticity are marked with green and MIRC strengths with unexpected tropicity are marked with turquoise

\begin{tabular}{ccccc} 
& \multicolumn{2}{c}{$\left(\mathrm{C}_{5} \mathrm{H}_{5}\right)_{2} \mathrm{MP}$} & \multicolumn{2}{c}{$\mathrm{H}_{2}-\left(\mathrm{C}_{5} \mathrm{H}_{5}\right)_{2} \mathrm{MP}$} \\
\cline { 2 - 5 } Metal & Singlet & Triplet & Singlet & Triplet \\
\hline $\mathrm{V}^{+}$ & 2.2 & -0.1 & 13.7 & 1.4 \\
$\mathrm{Cr}$ & 4.7 & 2.1 & 5.8 & 15.3 \\
$\mathrm{Mn}^{+}$ & 31.4 & -13.2 & -9.7 & 15.9 \\
$\mathrm{Fe}$ & -10.4 & 6.2 & 13.8 & -9.0 \\
$\mathrm{Co}{ }^{+}$ & -21.3 & 14.4 & 21.8 & 17.3 \\
$\mathrm{Ni}$ & 22.6 & -4.6 & 0.4 & 5.2 \\
$\mathrm{Mo}$ & 4.4 & 4.7 & 1.3 & 16.2 \\
$\mathrm{Tc}^{+}$ & 7.8 & -3.3 & -7.5 & -9.0 \\
$\mathrm{Ru}^{+}$ & -10.8 & 8.8 & 15.3 & -11.9 \\
$\mathrm{Rh}^{+}$ & -20.5 & 14.0 & 23.2 & -22.0
\end{tabular}

since the singlet states have $4 n+2$ electrons in the conjugated bonds, while $4 n$ electrons lead to antiaromaticity. The antiaromatic singlet states become an aromatic triplet state and vice versa, following the Baird rule for triplet-state aromaticity. ${ }^{49,50,52}$ The MIRC strengths are summarized in Table 1.

Previously calculated nucleus-independent magnetic shielding functions and experimental ${ }^{1} \mathrm{H}$ NMR chemical shifts also suggested that the singlet state of $\left(\mathrm{C}_{5} \mathrm{H}_{5}\right)_{2} \mathrm{FeP}$ is antiaromatic and the singlet state of $\mathrm{H}_{2}-\left(\mathrm{C}_{5} \mathrm{H}_{5}\right)_{2} \mathrm{FeP}$ is aromatic. ${ }^{22}$

The calculations showed that the ring current of the porphyrinoid part splits into an inner and an outer route at each heterocyclic ring. At the pyrrole rings of the singlet $\left(\mathrm{C}_{5} \mathrm{H}_{5}\right)_{2} \mathrm{FeP}$ it mainly follows the innermost pathway, whereas at the thiophene ring, the ring-current strength of the inner pathway is about a factor of two stronger than that of the outer one.

The calculations showed that the ring current of $\left(\mathrm{C}_{5} \mathrm{H}_{5}\right)_{2} \mathrm{FeP}$ in the porphyrinoid part splits into an inner and outer route at each heterocyclic ring. At the pyrrole rings of the singlet $\left(\mathrm{C}_{5} \mathrm{H}_{5}\right)_{2} \mathrm{FeP}$ it mainly follows the innermost pathway, whereas at the thiophene ring, the ring-current strength of the inner pathway is about a factor of two stronger than that of the outer one. The pyrrole rings sustain a weak local diatropic ring current of $1.6 \mathrm{nA} \mathrm{T}{ }^{-1}$. The strengths of the MIRC obtained by integrating the current density passing along selected chemical bonds are shown in Fig. 2. The main ring-current pathways of the singlet and triplet states of $\left(\mathrm{C}_{5} \mathrm{H}_{5}\right)_{2} \mathrm{FeP}$ and $\mathrm{H}_{2}-\left(\mathrm{C}_{5} \mathrm{H}_{5}\right)_{2} \mathrm{FeP}$ are shown in Fig. 3.

For the aromatic singlet state of $\mathrm{H}_{2}-\left(\mathrm{C}_{5} \mathrm{H}_{5}\right)_{2} \mathrm{FeP}$, the outer pathways of the diatropic MIRC dominate. The MIRC splits at the pyrrole rings, whereas the thiophene ring sustains a local 


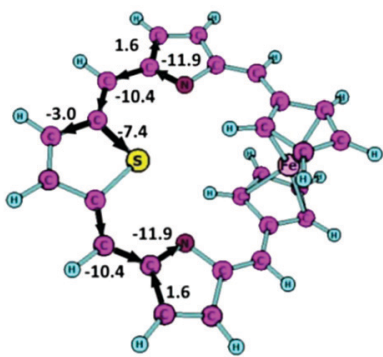

(a) Singlet state of $\left(\mathrm{C}_{5} \mathrm{H}_{5}\right)_{2} \mathrm{FeP}$

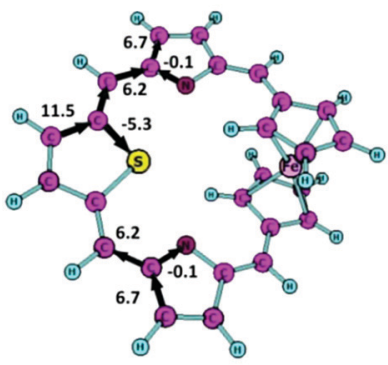

(c) Triplet state of $\left(\mathrm{C}_{5} \mathrm{H}_{5}\right)_{2} \mathrm{FeP}$

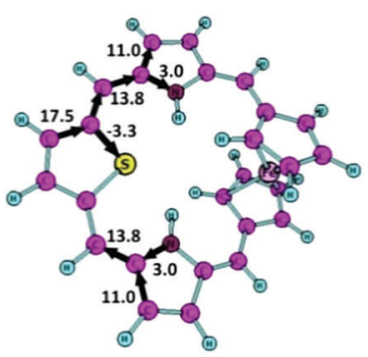

(b) Singlet state of $\mathrm{H}_{2}-\left(\mathrm{C}_{5} \mathrm{H}_{5}\right)_{2} \mathrm{FeP}$

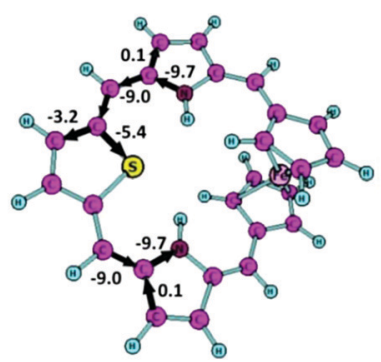

(d) Triplet state of $\mathrm{H}_{2}-\left(\mathrm{C}_{5} \mathrm{H}_{5}\right)_{2} \mathrm{FeP}$
Fig. 2 The strength of the MIRC (in $n A T^{-1}$ ) along selected bonds in the singlet and triplet states of $\left(\mathrm{C}_{5} \mathrm{H}_{5}\right)_{2} \mathrm{FeP}$ and $\mathrm{H}_{2}-\left(\mathrm{C}_{5} \mathrm{H}_{5}\right)_{2} \mathrm{FeP}$.

ring current of $-3.3 \mathrm{nA} \mathrm{T}^{-1}$. The diatropic MIRC of the aromatic triplet state $\left(\mathrm{C}_{5} \mathrm{H}_{5}\right)_{2} \mathrm{FeP}$ takes the outer route at the pyrrole and thiophene rings. The thiophene ring sustains a local ring current of $-5.3 \mathrm{nA} \mathrm{T}^{-1}$, whereas the current density does not take the inner route at the pyrrole rings.

The paratropic MIRC of the triplet state of $\mathrm{H}_{2}-\left(\mathrm{C}_{5} \mathrm{H}_{5}\right)_{2} \mathrm{FeP}$ takes the inner pathway at the pyrrole rings, whereas it splits into an inner and outer pathway at the thiophene ring. The current density along the inner pathway is almost a factor of two stronger than the one along the outer route. The strength of the MIRC pathways is shown in Fig. 2 and the dominating ring-current pathways are shown in Fig. 3, where diatropic ring currents are marked in blue and the paratropic ones are red. The current densities of the singlet state of $\left(\mathrm{C}_{5} \mathrm{H}_{5}\right)_{2} \mathrm{FeP}$ and $\mathrm{H}_{2}-\left(\mathrm{C}_{5} \mathrm{H}_{5}\right)_{2} \mathrm{FeP}$ are shown in Fig. 4 .

An unusual current-density topology was observed in the ferrocene unit. In the aromatic singlet $\mathrm{H}_{2}-\left(\mathrm{C}_{5} \mathrm{H}_{5}\right)_{2} \mathrm{FeP}$, the diatropic MIRC flows on the outside of the $\mathrm{C}_{5} \mathrm{H}_{5}$ ring when it arrives to the ferrocene moiety. It forms a helical flow in the ferrocene making an extra lap around the other $\mathrm{C}_{5} \mathrm{H}_{5}$ ring before it leaves the ferrocene moiety on the other side. The paratropic MIRC flows on the inside of the porphyrinoid part, taking a shortcut at the ferrocene from one $\mathrm{C}_{5} \mathrm{H}_{5}$ ring to the other on inside of the ferrocene moiety.

In the antiaromatic $\left(\mathrm{C}_{5} \mathrm{H}_{5}\right)_{2} \mathrm{FeP}$, the paratropic MIRC flows on the inside of the porphyrinoid ring. When it approaches the ferrocene moiety, it makes a lap around the $\mathrm{C}_{5} \mathrm{H}_{5}$ ring before it continues with a helical flow to the other $\mathrm{C}_{5} \mathrm{H}_{5}$ ring where it leaves the ferrocene moiety on the inside of the $\mathrm{C}_{5} \mathrm{H}_{5}$ ring. The paratropic MIRC also takes a shortcut on the inside from

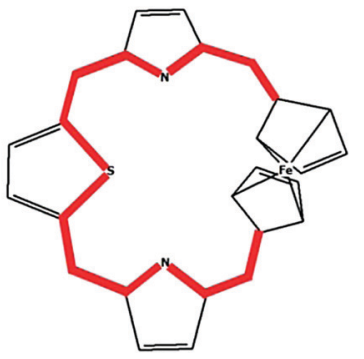

(a) Singlet state of $\left(\mathrm{C}_{5} \mathrm{H}_{5}\right)_{2} \mathrm{FeP}$

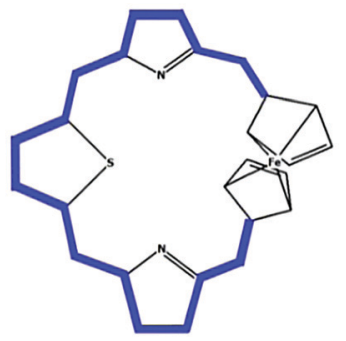

(c) Triplet state of $\left(\mathrm{C}_{5} \mathrm{H}_{5}\right)_{2} \mathrm{FeP}$

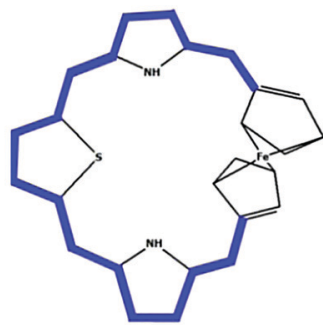

(b) Singlet state of $\mathrm{H}_{2-}$ $\left(\mathrm{C}_{5} \mathrm{H}_{5}\right)_{2} \mathrm{FeP}$

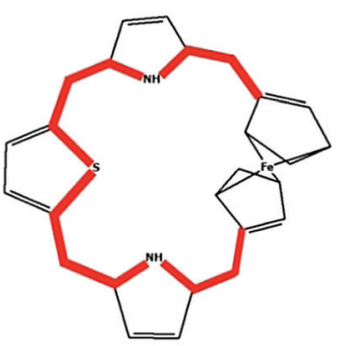

(d) Triplet state of $\mathrm{H}_{2-}$ $\left(\mathrm{C}_{5} \mathrm{H}_{5}\right)_{2} \mathrm{FeP}$
Fig. 3 (a) The dominating antiaromatic pathway (in red) of the singlet state of $\left(\mathrm{C}_{5} \mathrm{H}_{5}\right)_{2} \mathrm{FeP}$, (b) the dominating aromatic pathway (in blue) of the singlet state of $\mathrm{H}_{2}-\left(\mathrm{C}_{5} \mathrm{H}_{5}\right)_{2} \mathrm{FeP}$, (c) the dominating aromatic pathway (in blue) of the triplet state of $\left(\mathrm{C}_{5} \mathrm{H}_{5}\right)_{2} \mathrm{FeP}$, and (d) the dominating antiaromatic pathway (in red) of the triplet state of $\mathrm{H}_{2}-\left(\mathrm{C}_{5} \mathrm{H}_{5}\right)_{2} \mathrm{FeP}$.

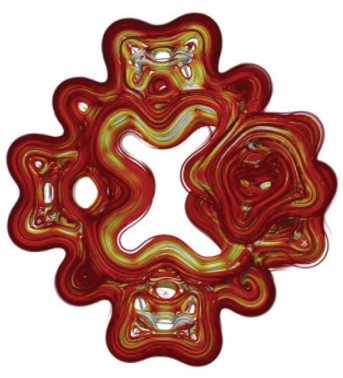

(a) $\left(\mathrm{C}_{5} \mathrm{H}_{5}\right)_{2} \mathrm{FeP}$

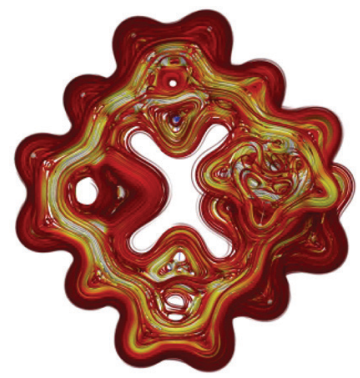

(b) $\mathrm{H}_{2}-\left(\mathrm{C}_{5} \mathrm{H}_{5}\right)_{2} \mathrm{FeP}$
Fig. 4 The current density of (a) the singlet state of $\left(\mathrm{C}_{5} \mathrm{H}_{5}\right)_{2} \mathrm{FeP}$ whose paratropic MIRC flows mainly on the inside; (b) the singlet state of $\mathrm{H}_{2}-\left(\mathrm{C}_{5} \mathrm{H}_{5}\right)_{2} \mathrm{FeP}$ with diatropic MIRC flowing along the outer pathway. The paratropic MIRC of $\mathrm{H}_{2}-\left(\mathrm{C}_{5} \mathrm{H}_{5}\right)_{2} \mathrm{FeP}$ on the inside of it is also seen. The helical current density at the ferrocene has the same chirality in both molecules. The current-density plots have been visualized using Paraview. ${ }^{53}$ The color scale represents the strength of the current density such that white is the strongest and black is the weakest one.

one $\mathrm{C}_{5} \mathrm{H}_{5}$ ring to the other as in $\mathrm{H}_{2}-\left(\mathrm{C}_{5} \mathrm{H}_{5}\right)_{2} \mathrm{FeP}$. The helical current density at the ferrocene moiety of the two molecules has the same chirality. The MIRC fluxes of $\left(\mathrm{C}_{5} \mathrm{H}_{5}\right)_{2} \mathrm{FeP}$ and $\mathrm{H}_{2}-\left(\mathrm{C}_{5} \mathrm{H}_{5}\right)_{2} \mathrm{FeP}$ are shown in Fig. 5(a) and (b), respectively. More streamline representations of the MIRC are shown in the ESI. $\dagger$

$\left(\mathrm{C}_{5} \mathrm{H}_{5}\right)_{2} \mathrm{RuP}, \mathrm{H}_{2}-\left(\mathrm{C}_{5} \mathrm{H}_{5}\right)_{2} \mathrm{RuP},\left(\mathrm{C}_{5} \mathrm{H}_{5}\right)_{2} \mathrm{RhP}^{+}$and $\mathrm{H}_{2}-\left(\mathrm{C}_{5} \mathrm{H}_{5}\right)_{2} \mathrm{RhP}^{+}$ are isoelectronic with the corresponding Fe compounds. Their aromatic character is the same as for the valence isoelectronic 


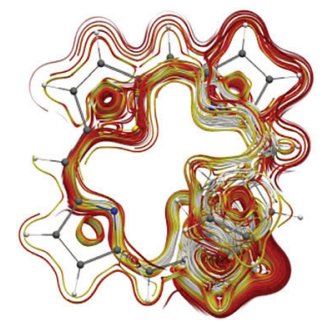

(a) $\left(\mathrm{C}_{5} \mathrm{H}_{5}\right)_{2} \mathrm{FeP}$

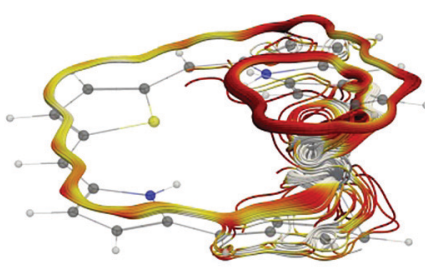

(b) $\mathrm{H}_{2}-\left(\mathrm{C}_{5} \mathrm{H}_{5}\right)_{2} \mathrm{FeP}$
Fig. 5 (a) The paratropic MIRC of $\left(\mathrm{C}_{5} \mathrm{H}_{5}\right){ }_{2} \mathrm{FeP}$ taking the inner pathway and the helical flux at the ferrocene moiety. (b) The diatropic MIRC of $\mathrm{H}_{2}-\left(\mathrm{C}_{5} \mathrm{H}_{5}\right)_{2} \mathrm{FeP}$ and the helical flux at the ferrocene. More pictures of the current densities and the MIRCs are shown in the ESI. $\dagger$ The currentdensity flow has been obtained using the Runge-Kutta algorithm in Paraview. ${ }^{53}$

[Fe]-cenothiaporphyrins. The MIRC of $\left(\mathrm{C}_{5} \mathrm{H}_{5}\right)_{2} \mathrm{RuP}$ and $\mathrm{H}_{2}$ $\left(\mathrm{C}_{5} \mathrm{H}_{5}\right)_{2} \mathrm{RuP}$ are $0.4-2.9 \mathrm{nA} \mathrm{T}^{-1}$ stronger than for the corresponding [Fe]-cenothiaporphyrins. The singlet ground state of $\left(\mathrm{C}_{5} \mathrm{H}_{5}\right)_{2} \mathrm{RuP}$ is antiaromatic sustaining a MIRC of $-10.8 \mathrm{nA} \mathrm{T}^{-1}$ and the singlet ground state of $\mathrm{H}_{2}-\left(\mathrm{C}_{5} \mathrm{H}_{5}\right)_{2} \mathrm{RuP}$ is aromatic with a MIRC of $15.3 \mathrm{nA} \mathrm{T}^{-1}$. The triplet state of $\left(\mathrm{C}_{5} \mathrm{H}_{5}\right)_{2} \mathrm{RuP}$ and $\mathrm{H}_{2}-\left(\mathrm{C}_{5} \mathrm{H}_{5}\right)_{2} \mathrm{RuP}$ lie $13.2 \mathrm{kcal} \mathrm{mol}^{-1}$ and $20.2 \mathrm{kcal} \mathrm{mol}^{-1}$ above the singlet ground state, respectively. The triplet state of $\left(\mathrm{C}_{5} \mathrm{H}_{5}\right)_{2} \mathrm{RuP}$ and $\mathrm{H}_{2}-\left(\mathrm{C}_{5} \mathrm{H}_{5}\right)_{2} \mathrm{RuP}$ sustains MIRC of $8.8 \mathrm{nA} \mathrm{T}^{-1}$ and $-11.9 \mathrm{nA} \mathrm{T}^{-1}$, respectively. The aromatic character of $\left(\mathrm{C}_{5} \mathrm{H}_{5}\right)_{2} \mathrm{RuP}$ and $\mathrm{H}_{2}-\left(\mathrm{C}_{5} \mathrm{H}_{5}\right)_{2}$ RuP follows the Hückel and Baird aromaticity rules.

The triplet state of $\left(\mathrm{C}_{5} \mathrm{H}_{5}\right)_{2} \mathrm{RhP}^{+}$is $10.0 \mathrm{kcal} \mathrm{mol}^{-1}$ and the triplet state of $\mathrm{H}_{2}-\left(\mathrm{C}_{5} \mathrm{H}_{5}\right)_{2} \mathrm{RhP}^{+}$is $22.8 \mathrm{kcal} \mathrm{mol}^{-1}$ above the corresponding singlet ground states. The MIRC of the singlet ground state of $\left(\mathrm{C}_{5} \mathrm{H}_{5}\right)_{2} \mathrm{RhP}^{+}$is $-20.5 \mathrm{nA} \mathrm{T}^{-1}$ and in the MIRC of singlet ground state of $\mathrm{H}_{2}-\left(\mathrm{C}_{5} \mathrm{H}_{5}\right)_{2} \mathrm{RhP}^{+}$is $23.2 \mathrm{nA} \mathrm{T}^{-1}$. Since the triplet states of $\left(\mathrm{C}_{5} \mathrm{H}_{5}\right)_{2} \mathrm{RhP}^{+}$and $\mathrm{H}_{2}-\left(\mathrm{C}_{5} \mathrm{H}_{5}\right)_{2} \mathrm{RhP}^{+}$also have reverse aromatic character as compared to the singlet ground states, their aromatic character follows the Hückel and Baird aromaticity rules.

$\left(\mathrm{C}_{5} \mathrm{H}_{5}\right)_{2} \mathrm{CoP}^{+}$and $\mathrm{H}_{2}-\left(\mathrm{C}_{5} \mathrm{H}_{5}\right)_{2} \mathrm{CoP}^{+}$are isoelectronic with the corresponding $[\mathrm{Fe}]$-cenothiaporphyrins. When oxidizing metallocenes, the electronic charge is mainly removed from the $\mathrm{C}_{5} \mathrm{H}_{5}$ rings implying that the electron configuration of $\mathrm{Co}^{+}$remains largely as $4 \mathrm{~s}^{0} 3 \mathrm{~d}^{8}$. The same holds for the other cations of this study. ${ }^{54,55}$ However, the triplet state of $\mathrm{H}_{2}-\left(\mathrm{C}_{5} \mathrm{H}_{5}\right)_{2} \mathrm{CoP}^{+}$has a d occupation of 7.7 as compared to 8.2 for the other Co compounds. Thus, the exciton of the triplet state is partly localized to the metal leading to aromaticity of the triplet state of $\mathrm{H}_{2}-\left(\mathrm{C}_{5} \mathrm{H}_{5}\right)_{2} \mathrm{CoP}^{+}$instead of antiaromaticity as estimated from the Baird rule. The singlet ground state of $\left(\mathrm{C}_{5} \mathrm{H}_{5}\right)_{2} \mathrm{CoP}^{+}$and $\mathrm{H}_{2}-\left(\mathrm{C}_{5} \mathrm{H}_{5}\right)_{2} \mathrm{CoP}^{+}$are $7.6 \mathrm{kcal} \mathrm{mol}^{-1}$ and $9.1 \mathrm{kcal} \mathrm{mol}^{-1}$, respectively below the triplet state. The aromatic character of $\left(\mathrm{C}_{5} \mathrm{H}_{5}\right)_{2} \mathrm{CoP}^{+}$ follows the Hückel and Baird aromaticity rules. The singlet ground state is antiaromatic sustaining a MIRC of $-21.3 \mathrm{nA} \mathrm{T}^{-1}$ and the triplet state is aromatic sustaining an MIRC of 14.4 nA T The singlet ground state of $\mathrm{H}_{2}-\left(\mathrm{C}_{5} \mathrm{H}_{5}\right)_{2} \mathrm{CoP}^{+}$is aromatic as expected from Hückel's aromaticity rule. It sustains an MIRC of $21.8 \mathrm{nA} \mathrm{T} \mathrm{T}^{-1}$, whereas the triplet state of $\mathrm{H}_{2}-\left(\mathrm{C}_{5} \mathrm{H}_{5}\right)_{2} \mathrm{CoP}^{+}$is unexpectedly also aromatic sustaining a strong diatropic MIRC of $17.3 \mathrm{nA} \mathrm{T}^{-1}$ implying that it does not follow Baird's aromaticity rule.

\section{Group VI and isoelectronic compounds}

The $\left(\mathrm{C}_{5} \mathrm{H}_{5}\right)_{2} \mathrm{MnP}^{+}$and $\mathrm{H}_{2}-\left(\mathrm{C}_{5} \mathrm{H}_{5}\right)_{2} \mathrm{MnP}^{+}$cations have an even number of electrons and two electrons less than the corresponding [Fe]-cenothiaporphyrins. The aromatic character and the aromatic pathways are therefore reversed as compared to the Fe containing compounds. The dominating pathways of the MIRC of the singlet and triplet states of $\left(\mathrm{C}_{5} \mathrm{H}_{5}\right)_{2} \mathrm{MnP}^{+}$and $\mathrm{H}_{2}-\left(\mathrm{C}_{5} \mathrm{H}_{5}\right)_{2} \mathrm{MnP}^{+}$are shown in Fig. 6. However, $\left(\mathrm{C}_{5} \mathrm{H}_{5}\right)_{2} \mathrm{MnP}^{+}$ and $\mathrm{H}_{2}-\left(\mathrm{C}_{5} \mathrm{H}_{5}\right)_{2} \mathrm{MnP}^{+}$have a triplet ground state with the singlet state lying $24.1 \mathrm{kcal} \mathrm{mol}^{-1}$ and $18.0 \mathrm{kcal} \mathrm{mol}^{-1}$ higher in energy, respectively. Calculations of the current density for the singlet state of $\left(\mathrm{C}_{5} \mathrm{H}_{5}\right)_{2} \mathrm{MnP}^{+}$show that it is aromatic sustaining a MIRC of $31.4 \mathrm{nA} \mathrm{T}^{-1}$. The triplet state is antiaromatic with a MIRC of $-13.2 \mathrm{nA} \mathrm{T}^{-1}$. The aromatic character of $\left(\mathrm{C}_{5} \mathrm{H}_{5}\right)_{2} \mathrm{MnP}^{+}$ follows the Hückel and Baird rules, because it has $4 n+2$ electrons in the bond conjugation. The aromatic character of $\mathrm{H}_{2}-\left(\mathrm{C}_{5} \mathrm{H}_{5}\right)_{2} \mathrm{MnP}^{+}$also follows the Hückel and Baird rules, since its singlet state is antiaromatic sustaining a MIRC of $-9.7 \mathrm{nA} \mathrm{T}^{-1}$ and the triplet state is aromatic with a MIRC of $15.9 \mathrm{nA} \mathrm{T}^{-1}$.

The strengths of the MIRC along selected bonds are shown in Fig. 7. The ring current of the singlet state of $\left(\mathrm{C}_{5} \mathrm{H}_{5}\right)_{2} \mathrm{MnP}^{+}$ splits at the pyrrole and thiophene rings. The current-density flux is about three times stronger along the outer route. The ring current of the triplet state follows mainly along the

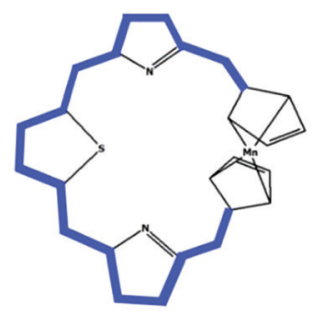

(a) Singlet state of $\left(\mathrm{C}_{5} \mathrm{H}_{5}\right)_{2} \mathrm{MnP}^{+}$

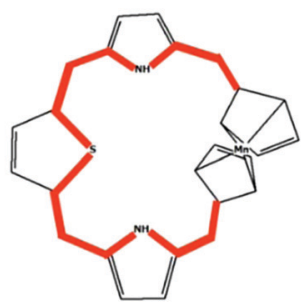

(c) Triplet state of $\left(\mathrm{C}_{5} \mathrm{H}_{5}\right)_{2} \mathrm{MnP}^{+}$

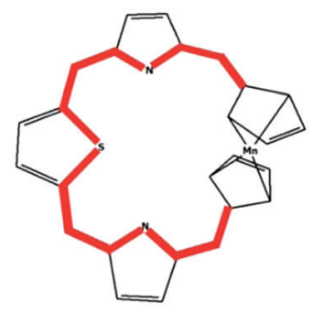

(b) Singlet state of $\mathrm{H}_{2}-\left(\mathrm{C}_{5} \mathrm{H}_{5}\right)_{2} \mathrm{MnP}^{+}$

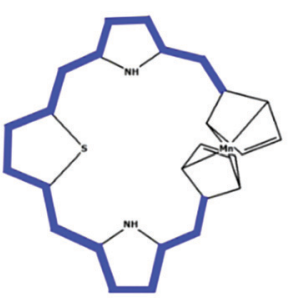

(d) Triplet state of $\mathrm{H}_{2}-\left(\mathrm{C}_{5} \mathrm{H}_{5}\right)_{2} \mathrm{MnP}^{+}$
Fig. 6 (a) The dominating aromatic pathway (in blue) of the singlet state of $\left(\mathrm{C}_{5} \mathrm{H}_{5}\right)_{2} \mathrm{MnP}^{+}$, (b) the dominating antiaromatic pathway (in red) of the singlet state of $\mathrm{H}_{2}-\left(\mathrm{C}_{5} \mathrm{H}_{5}\right)_{2} \mathrm{MnP}^{+}$, (c) the dominating antiaromatic pathway (in red) of the triplet state of $\left(\mathrm{C}_{5} \mathrm{H}_{5}\right)_{2} \mathrm{MnP}^{+}$, and (d) the dominating aromatic pathway (in blue) of the triplet state of $\mathrm{H}_{2}-\left(\mathrm{C}_{5} \mathrm{H}_{5}\right)_{2} \mathrm{MnP}^{+}$. 


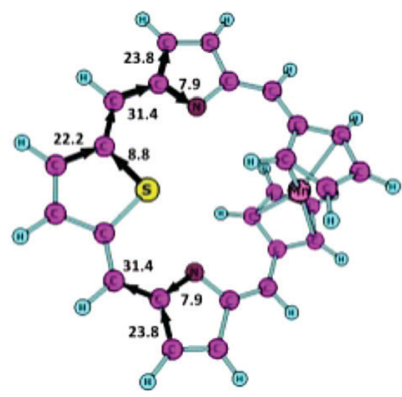

(a) singlet $\left(\mathrm{C}_{5} \mathrm{H}_{5}\right)_{2} \mathrm{MnP}^{+}$

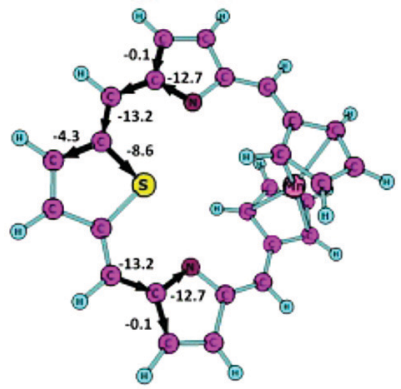

(c) triplet $\left(\mathrm{C}_{5} \mathrm{H}_{5}\right)_{2} \mathrm{MnP}^{+}$

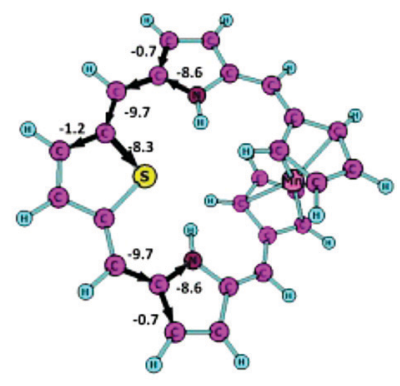

(b) singlet $\mathrm{H}_{2}-\left(\mathrm{C}_{5} \mathrm{H}_{5}\right)_{2} \mathrm{MnP}^{+}$

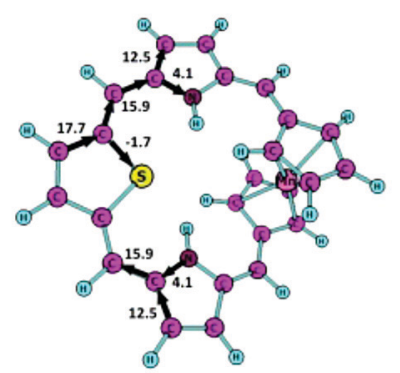

(d) triplet $\mathrm{H}_{2}-\left(\mathrm{C}_{5} \mathrm{H}_{5}\right)_{2} \mathrm{MnP}^{+}$

Fig. 7 The strength of the MIRC (in $n A^{-1}$ ) along selected bonds in (a) the singlet state of $\left(\mathrm{C}_{5} \mathrm{H}_{5}\right)_{2} \mathrm{MnP}^{+}$, (b) the singlet state of $\mathrm{H}_{2}-\left(\mathrm{C}_{5} \mathrm{H}_{5}\right)_{2} \mathrm{MnP}^{+}$ (c) the triplet state of $\left(\mathrm{C}_{5} \mathrm{H}_{5}\right)_{2} \mathrm{MnP}^{+}$and (d) the triplet state of $\mathrm{H}_{2}-\left(\mathrm{C}_{5} \mathrm{H}_{5}\right)_{2} \mathrm{MnP}^{+}$.

innermost pathway. It splits into an inner and an outer route at the thiophene ring. However, the inner one is twice as strong as the outer branch. The ring-current pathway of the singlet state of $\mathrm{H}_{2}-\left(\mathrm{C}_{5} \mathrm{H}_{5}\right)_{2} \mathrm{MnP}^{+}$is similar to the one for the triplet state of $\left(\mathrm{C}_{5} \mathrm{H}_{5}\right)_{2} \mathrm{MnP}^{+}$. The diatropic ring current of the triplet state of $\mathrm{H}_{2}-\left(\mathrm{C}_{5} \mathrm{H}_{5}\right)_{2} \mathrm{MnP}^{+}$splits into an outer and inner branch at the pyrrole rings, whereas the thiophene ring sustains a weak local diatropic ring current. The outer pathway at the pyrrole rings is about three times stronger than the inner one.

The ground state of the neutral $\left(\mathrm{C}_{5} \mathrm{H}_{5}\right)_{2} \mathrm{MnP}$ and $\mathrm{H}_{2}-\left(\mathrm{C}_{5} \mathrm{H}_{5}\right)_{2} \mathrm{MnP}$ molecules is a sextet state. Calculations of the current density of the neutral $\left(\mathrm{C}_{5} \mathrm{H}_{5}\right)_{2} \mathrm{MnP}$ and $\mathrm{H}_{2}-\left(\mathrm{C}_{5} \mathrm{H}_{5}\right)_{2} \mathrm{MnP}$ show that they are non-aromatic sustaining a very weak MIRC of $1.5 \mathrm{nA} \mathrm{T}^{-1}$ and $0.9 \mathrm{nA} \mathrm{T}^{-1}$, respectively. The pyrrole and thiophene rings of $\left(\mathrm{C}_{5} \mathrm{H}_{5}\right)_{2} \mathrm{MnP}$ sustain a local diatropic MIRC of $3.4 \mathrm{nA} \mathrm{T}^{-1}$. The local ring current of the thiophene ring of $\mathrm{H}_{2}-\left(\mathrm{C}_{5} \mathrm{H}_{5}\right)_{2} \mathrm{MnP}$ is $6.9 \mathrm{nA} \mathrm{T}{ }^{-1}$, whereas the pyrrole rings sustain a weak local MIRC of $2.6 \mathrm{nA} \mathrm{T}^{-1}$. The long distance between $\mathrm{Mn}$ and the $\mathrm{C}_{5} \mathrm{H}_{5}$ rings (see Table $\mathrm{S} 1$ in the ESI $\dagger$ ) suggests that the sextet ground state of the neutral $\left(\mathrm{C}_{5} \mathrm{H}_{5}\right)_{2} \mathrm{MnP}$ and $\mathrm{H}_{2}-\left(\mathrm{C}_{5} \mathrm{H}_{5}\right)_{2} \mathrm{MnP}$ is weakly bound. The distance between $\mathrm{Mn}$ and the $\mathrm{C}_{5} \mathrm{H}_{5}$ rings is much shorter for the cations.

The aromatic character of the [Cr]- and [Mo]cenothiaporphyrins are similar. The triplet ground state of $\left(\mathrm{C}_{5} \mathrm{H}_{5}\right)_{2} \mathrm{CrP}$ and $\left(\mathrm{C}_{5} \mathrm{H}_{5}\right)_{2} \mathrm{MoP}$ sustain a weak diatropic MIRC of $2.1 \mathrm{nA} \mathrm{T}^{-1}$ and $4.7 \mathrm{nA} \mathrm{T}^{-1}$, respectively. However, according to the aromaticity rules, one would expect them to sustain a paratropic MIRC. The singlet states of $\left(\mathrm{C}_{5} \mathrm{H}_{5}\right)_{2} \mathrm{CrP}$ and $\left(\mathrm{C}_{5} \mathrm{H}_{5}\right)_{2} \mathrm{MoP}$ that lie $29.5 \mathrm{kcal} \mathrm{mol}^{-1}$ and $2.1 \mathrm{kcal} \mathrm{mol}^{-1}$ higher

in energy are weakly aromatic following Hückel's rule with MIRC strengths of $4.7 \mathrm{nA} \mathrm{T^{-1 }}$ and $4.4 \mathrm{nA} \mathrm{T}^{-1}$, respectively. The triplet ground state of $\mathrm{H}_{2}-\left(\mathrm{C}_{5} \mathrm{H}_{5}\right)_{2} \mathrm{CrP}$ and $\mathrm{H}_{2}-\left(\mathrm{C}_{5} \mathrm{H}_{5}\right)_{2} \mathrm{MoP}$ is strongly aromatic sustaining an MIRC of $15.3 \mathrm{nA} \mathrm{T}^{-1}$ and $16.2 \mathrm{nA} \mathrm{T}^{-1}$, respectively, which is also predicted from Hückel's and Baird's aromaticity rules. However, their singlet states lying $23.6 \mathrm{kcal} \mathrm{mol}^{-1}$ and $10.2 \mathrm{kcal} \mathrm{mol}^{-1}$ above the triplet state also sustain a diatropic MIRC. The ring-current strength of $\mathrm{H}_{2}-\left(\mathrm{C}_{5} \mathrm{H}_{5}\right)_{2} \mathrm{CrP}$ is $5.8 \mathrm{nA} \mathrm{T}^{-1}$ indicating weak aromaticity, whereas the strength of the MIRC of $\mathrm{H}_{2}-\left(\mathrm{C}_{5} \mathrm{H}_{5}\right)_{2} \mathrm{MoP}$ is only $1.3 \mathrm{nA} \mathrm{T}^{-1}$ suggesting that it is nonaromatic. The partially ionic nature of the chemical bond between the metal and the $\mathrm{C}_{5} \mathrm{H}_{5}$ might be the reason for the unexpected aromatic properties of the $[\mathrm{Cr}]-$ and $[\mathrm{Mo}]$-cenothiaporphyrins. ${ }^{2}$

\section{Group VI and isoelectronic compounds}

The singlet and triplet states of the $\left(\mathrm{C}_{5} \mathrm{H}_{5}\right)_{2} \mathrm{TcP}^{+}$and $\mathrm{H}_{2}-\left(\mathrm{C}_{5} \mathrm{H}_{5}\right)_{2} \mathrm{TcP}^{+}$ cations are almost degenerate. The singlet state of $\mathrm{H}_{2}-\left(\mathrm{C}_{5} \mathrm{H}_{5}\right)_{2} \mathrm{TcP}^{+}$ is $2.2 \mathrm{kcal} \mathrm{mol}^{-1}$ below the triplet, whereas the triplet state of $\left(\mathrm{C}_{5} \mathrm{H}_{5}\right)_{2} \mathrm{TcP}^{+}$is energetically $2.1 \mathrm{kcal} \mathrm{mol}^{-1}$ lower than the singlet. The aromatic character of the [Tc]-cenothiaporphyrin cations follows the Hückel and Baird aromaticity rules, except for the triplet state of $\mathrm{H}_{2}-\left(\mathrm{C}_{5} \mathrm{H}_{5}\right)_{2} \mathrm{TcP}^{+}$, which is unexpectedly antiaromatic, sustaining a paratropic MIRC of $-9.0 \mathrm{nA} \mathrm{T}^{-1}$. The singlet state of $\left(\mathrm{C}_{5} \mathrm{H}_{5}\right)_{2} \mathrm{TcP}^{+}$is aromatic with a MIRC of $7.8 \mathrm{nA} \mathrm{T}^{-1}$ and the singlet state of $\mathrm{H}_{2}-\left(\mathrm{C}_{5} \mathrm{H}_{5}\right)_{2} \mathrm{TcP}^{+}$is antiaromatic with a paratropic MIRC of $-7.5 \mathrm{nA} \mathrm{T}^{-1}$. The triplet state of $\left(\mathrm{C}_{5} \mathrm{H}_{5}\right)_{2} \mathrm{TcP}^{+}$has a weak paratropic MIRC of $-3.3 \mathrm{nA} \mathrm{T}^{-1}$. The electron configuration of the singlet state of $\mathrm{H}_{2}-\left(\mathrm{C}_{5} \mathrm{H}_{5}\right)_{2} \mathrm{TcP}^{+}$is $5 \mathrm{~s}^{0} 4 \mathrm{~d}^{6.7}$ and the charge of the metal is $0.1 e$, whereas the triplet state of $\mathrm{H}_{2}-\left(\mathrm{C}_{5} \mathrm{H}_{5}\right)_{2} \mathrm{TcP}^{+}$has 6.3 electrons in the $\mathrm{d}$ shell and a charge of $0.4 e$ on the metal. The exciton of the triplet state of $\mathrm{H}_{2}-\left(\mathrm{C}_{5} \mathrm{H}_{5}\right)_{2} \mathrm{TcP}^{+}$is partly located to the atom, implying that it does not follow the Baird rule.

The sextet ground state of the neutral $\left(\mathrm{C}_{5} \mathrm{H}_{5}\right)_{2} \mathrm{TcP}$ is antiaromatic sustaining a MIRC of $-10.3 \mathrm{nA} \mathrm{T}^{-1}$. The MIRC of the sextet ground state of the neutral $\mathrm{H}_{2}-\left(\mathrm{C}_{5} \mathrm{H}_{5}\right)_{2} \mathrm{TcP}$ is $16.3 \mathrm{nA} \mathrm{T}^{-1}$ showing that it is aromatic. The singlet and triplet states are $90.0 \mathrm{kcal} \mathrm{mol}{ }^{-1}$ and $87.9 \mathrm{kcal} \mathrm{mol}^{-1}$ higher in energy.

\section{Group X compounds}

The [Ni]-cenothiaporphyrins have two electrons more than the $[\mathrm{Fe}]$-cenothiaporphyrins. Thus, one expects a reverse aromatic nature as compared to the Fe compounds according to the Hückel and Baird aromaticity rules. The singlet state of $\left(\mathrm{C}_{5} \mathrm{H}_{5}\right)_{2} \mathrm{NiP}$ is indeed strongly aromatic with a MIRC of $22.6 \mathrm{nA} \mathrm{T} \mathrm{T}^{-1}$, but the singlet state of $\mathrm{H}_{2}-\left(\mathrm{C}_{5} \mathrm{H}_{5}\right)_{2} \mathrm{NiP}$ is nonaromatic with a weak MIRC of $0.4 \mathrm{nA} \mathrm{T}^{-1}$. However, $\left(\mathrm{C}_{5} \mathrm{H}_{5}\right)_{2} \mathrm{NiP}$ and $\mathrm{H}_{2}-\left(\mathrm{C}_{5} \mathrm{H}_{5}\right)_{2} \mathrm{NiP}$ have triplet ground states that are $4.4 \mathrm{kcal} \mathrm{mol}^{-1}$ and $8.1 \mathrm{kcal} \mathrm{mol}^{-1}$ below the singlet state. The triplet state of $\left(\mathrm{C}_{5} \mathrm{H}_{5}\right)_{2} \mathrm{NiP}$ is weakly antiaromatic with a MIRC of $-4.6 \mathrm{nA} \mathrm{T}^{-1}$ and the triplet state of $\mathrm{H}_{2}-\left(\mathrm{C}_{5} \mathrm{H}_{5}\right)_{2} \mathrm{NiP}$ is weakly aromatic sustaining a diatropic MIRC of $5.2 \mathrm{nA} \mathrm{T}^{-1}$.

\section{Group IV compounds}

The vanadium-containing $\left(\mathrm{C}_{5} \mathrm{H}_{5}\right)_{2} \mathrm{VP}^{+}$and $\mathrm{H}_{2}-\left(\mathrm{C}_{5} \mathrm{H}_{5}\right)_{2} \mathrm{VP}^{+}$are isoelectronic to group IV elements. They have formally only two 
valence electrons on the metal atom that can contribute to the bond conjugation and the aromatic pathway, which may explain why three of the four [V]-cenothiaporphyrins sustain very weak ring currents. The strengths of the MIRC of the ground triplet states of $\left(\mathrm{C}_{5} \mathrm{H}_{5}\right)_{2} \mathrm{VP}^{+}$and $\mathrm{H}_{2}-\left(\mathrm{C}_{5} \mathrm{H}_{5}\right)_{2} \mathrm{VP}^{+}$are $-0.1 \mathrm{nA} \mathrm{T}^{-1}$ and $1.4 \mathrm{nA} \mathrm{T}^{-1}$, respectively. The singlet state of $\left(\mathrm{C}_{5} \mathrm{H}_{5}\right)_{2} \mathrm{VP}^{+}$that lies $21.7 \mathrm{kcal} \mathrm{mol}^{-1}$ above the triplet ground state sustains a weak diatropic MIRC of $2.2 \mathrm{nA} \mathrm{T}^{-1}$. The singlet state of $\mathrm{H}_{2}-\left(\mathrm{C}_{5} \mathrm{H}_{5}\right)_{2} \mathrm{VP}^{+}$lying $30.5 \mathrm{kcal} \mathrm{mol}^{-1}$ above the triplet is aromatic sustaining a MIRC of $13.7 \mathrm{nA} \mathrm{T}^{-1}$, which is also expected based on the aromatic nature of $\mathrm{H}_{2}-\left(\mathrm{C}_{5} \mathrm{H}_{5}\right)_{2} \mathrm{FeP}$ when using Hückel's aromaticity rule.

The quartet state of the neutral $\left(\mathrm{C}_{5} \mathrm{H}_{5}\right)_{2} \mathrm{VP}$ is antiaromatic sustaining a MIRC of $-6.0 \mathrm{nA} \mathrm{T}^{-1}$, which can indeed be deduced from the antiaromatic character of $\left(\mathrm{C}_{5} \mathrm{H}_{5}\right)_{2} \mathrm{FeP}$. In $\left(\mathrm{C}_{5} \mathrm{H}_{5}\right)_{2} \mathrm{FeP}$, the three valence orbitals of the metal are doubly occupied, whereas in the quartet state of the neutral $\left(\mathrm{C}_{5} \mathrm{H}_{5}\right)_{2} \mathrm{VP}$ they are singly occupied. The aromatic character of the quartet state of $\mathrm{H}_{2}-\left(\mathrm{C}_{5} \mathrm{H}_{5}\right)_{2} \mathrm{VP}$ can similarly be obtained from the aromatic nature of $\mathrm{H}_{2}-\left(\mathrm{C}_{5} \mathrm{H}_{5}\right)_{2} \mathrm{FeP}$, since the same number of orbitals of the metal are occupied in both cases even though it has three electrons less. $\mathrm{H}_{2}-\left(\mathrm{C}_{5} \mathrm{H}_{5}\right)_{2} \mathrm{VP}$ is indeed aromatic with a MIRC of $8.6 \mathrm{nA} \mathrm{T}^{-1}$.

\section{Conclusions}

The magnetically induced current-density susceptibility tensor (CDT) has been studied for the lowest singlet and triplet states of the metallocenothiaporphyrins, where the metal $\mathrm{M}$ is $\mathrm{V}, \mathrm{Cr}$, $\mathrm{Mn}, \mathrm{Fe}, \mathrm{Co}, \mathrm{Ni}, \mathrm{Mo}, \mathrm{Tc}, \mathrm{Ru}$, or Rh. The cations of the V, Mn, Co, Tc or Rh compounds were studied because the neutral molecules have an odd number of electrons. The relative energy of the singlet and triplet states are reported in Table S2 of the ESI. $\dagger$ The ground states of the metallocenothiaporphyrins have largely the same spin state as the corresponding metallocenes. ${ }^{56-58}$ See Table S3 of the ESI. $\dagger$ The wave functions of the studied molecules are expected to be dominated by a single slater determinant as for the metallocenes. ${ }^{1}$ The CDT was calculated using the gauge-including magnetically induced currents (GIMIC) method. Strengths of the magnetically induced ring currents (MIRC) were obtained by integrating the CDT passing through integration planes across specific chemical bonds. The strength and direction of the MIRC yield the aromatic character, the degree of aromaticity, and the ring-current pathway. The calculations show that the aromatic nature of most of the studied molecules can be estimated from the Hückel and Baird aromaticity rules. For the singlet and triplet states of the four compounds that are isoelectronic to the Fe compounds, only the triplet state of $\mathrm{H}_{2}-\left(\mathrm{C}_{5} \mathrm{H}_{5}\right)_{2} \mathrm{CoP}^{+}$has incorrect tropicity judged from the Baird aromaticity rule. The triplet state of $\mathrm{H}_{2}-\left(\mathrm{C}_{5} \mathrm{H}_{5}\right)_{2} \mathrm{TcP}^{+}$is antiaromatic, while the triplet state of $\left(\mathrm{C}_{5} \mathrm{H}_{5}\right)_{2} \mathrm{MoP}$ and the singlet state of $\mathrm{H}_{2}-\left(\mathrm{C}_{5} \mathrm{H}_{5}\right)_{2} \mathrm{CrP}$ are aromatic, although the Hückel and Baird aromaticity rules suggest the opposite behaviour. The same holds for six other states. However, their MIRC are very weak (smaller than $3 \mathrm{nA} \mathrm{T}^{-1}$ ). Hence, they should be considered nonaromatic. Population analysis suggests that triplet states do not follow the Baird aromaticity rule when their exciton is partly located to the metal. Three of the four [V]-cenothiaporphyrins are nonaromatic probably because the ligand-metal bonding in vanadocene and chromocene is partly ionic. They have an electron configuration of $4 \mathrm{~s}^{0} 3 \mathrm{~d}^{4}$ but formally only two valence electrons to transport the ring current across the metallocene.

GIMIC calculations on the high-spin states of the neutral metallocenothiaporphyrins with $\mathrm{M}=\mathrm{V}, \mathrm{Mn}, \mathrm{Co}$, Tc or Rh show that the Hückel and Baird aromaticity rules can be unified. The combined Hückel and Baird aromaticity rules that molecules with an odd number $(2 n+1)$ of occupied orbitals in the bond conjugation are aromatic, whereas molecules with an even number $(2 n)$ of occupied conjugation orbitals are antiaromatic. The sextet ground state of $\left(\mathrm{C}_{5} \mathrm{H}_{5}\right)_{2} \mathrm{TcP}$ has 15 spin-down electrons and 20 spin-up valence electrons. The electrons occupy 20 conjugated orbitals of which 5 are singly occupied. Since the number of occupied orbitals is even, the molecule is antiaromatic according to the present orbital-count rule of aromaticity. Our calculations showed that the sextet state of the $\left(\mathrm{C}_{5} \mathrm{H}_{5}\right)_{2} \mathrm{TcP}$ is indeed antiaromatic sustaining a MIRC of $-10.3 \mathrm{nA} \mathrm{T} \mathrm{T}^{-1}$. $\mathrm{H}_{2}-\left(\mathrm{C}_{5} \mathrm{H}_{5}\right)_{2} \mathrm{TcP}$ with a MIRC of $16.3 \mathrm{nA} \mathrm{T}^{-1}$ has 21 conjugated valence orbitals. The sextet state of $\mathrm{H}_{2}-\left(\mathrm{C}_{5} \mathrm{H}_{5}\right)_{2} \mathrm{TcP}$ is expected to be aromatic because it has an odd number of conjugated orbitals. The Hückel rule of aromaticity is covered by the combined aromaticity orbital-count rule, since in closed-shell molecules, all orbitals are doubly occupied, yielding the well-known $4 n+2$ electron-count rule. The Baird aromaticity rule for triplet states is also part of the combined aromaticity rule that can be employed for high-spin states such as those studied in this work.

The calculations show that the singlet ground state of [Fe]cenothiaporphyrin $\left(\left(\mathrm{C}_{5} \mathrm{H}_{5}\right)_{2} \mathrm{FeP}\right)$ is antiaromatic sustaining a paratropic MIRC of $-10.8 \mathrm{nA} \mathrm{T}^{-1}$ and that the singlet ground state of dihydro[Fe]-cenothiaporphyrin $\left(\mathrm{H}_{2}-\left(\mathrm{C}_{5} \mathrm{H}_{5}\right)_{2} \mathrm{FeP}\right)$ is aromatic sustaining a diatropic MIRC of $13.8 \mathrm{nA} \mathrm{T}^{-1}$. The lowest triplet states of $\left(\mathrm{C}_{5} \mathrm{H}_{5}\right)_{2} \mathrm{FeP}$ and $\mathrm{H}_{2}-\left(\mathrm{C}_{5} \mathrm{H}_{5}\right)_{2} \mathrm{FeP}$ are aromatic and antiaromatic, respectively. Calculations of the current density reveal a helical flow at the ferrocene moiety, whose chirality is the same for both the aromatic and antiaromatic molecules. The aromatic character of the studied metallocenothiaporphyrins with a noticeable MIRC $\left(I>3 \mathrm{nA} \mathrm{T}^{-1}\right)$ can with a few exceptions, be obtained by applying the combined Hückel-Baird aromaticity rule. The obtained ringcurrent strengths and aromatic character of the studied molecules are summarized in Table 1, where the MIRC strength is colour-coded according to its tropicity. When the molecule follows the Hückel and Baird rules, the table has two red numbers and two blue numbers on the corresponding row. The green background of the MIRC strength indicates that the molecule can be considered nonaromatic, whereas incorrect tropicity is marked with a turquoise background.

\section{Conflicts of interest}

There are no conflicts to declare. 


\section{Acknowledgements}

This work has been supported by the Academy of Finland through project number 314821, by the Magnus Ehrnrooth Foundation, the Finnish Cultural Foundation, and the Swedish Cultural Foundation in Finland. V. N. Cherepanov thanks the Russian Scientific Foundation (18-19-00268-II). We acknowledge computational resources from the Finnish Grid and Cloud Infrastructure (persistent identifier urn:nbn:fi:research-infras2016072533) and the CSC-IT Center for Science, Finland.

\section{Notes and references}

1 Z.-F. Xu, Y. Xie, W.-L. Feng and H. F. Schaefer, J. Phys. Chem. A, 2003, 107, 2716-2729.

2 F. A. Cotton and G. Wilksinson, Advanced Inorganic Chemistry: A Comprehensive Text, John Wiley \& Sons, 2nd edn, 1967.

3 C. Elschenbroich, Organometallics, Wiley-VCH, 3rd edn, 2006. 4 T. J. Kealy and P. L. Pauson, Nature, 1951, 168, 1039-1040.

5 S. A. Miller, J. A. Tebboth and J. F. Tremaine, J. Chem. Soc., 1952, 114, 632-635.

6 G. Wilkinson, M. Rosenblum, M. C. Whiting and R. B. Woodward, J. Am. Chem. Soc., 1952, 74, 2125-2126.

7 E. O. Fischer and W. Pfab, Z. Naturforsch. B, 1952, 7, 377-379.

8 K. P. Schug, H.-J. Guttmann, A. W. Preuss and K. Schädlich, SAE Tech. Pap., 1990, 900154.

9 K. Park, D. Yeo, S. Oh, H. Kim, M. Hoon Ha, H. Oh, M. Park, J. Park, D. Park, D. Jung, H. Chae, H. Kim and J.-H. Boo, Adv. Mater. Res., 2011, 415-417, 1360-1363.

10 A. Xia, J. E. Knox, M. J. Heeg, H. B. Schlegel and Ch. H. Winter, Organometallics, 2003, 22, 4060-4069.

11 R. A. Collins, A. F. Russell and P. Mountford, Appl. Petrochem. Res., 2015, 5, 153-171.

12 H. Köpf and P. Köpf-Maier, Angew. Chem., Int. Ed. Engl., 1979, 18, 477-478.

13 J. B. Waern, C. T. Dillon and M. M. Harding, J. Med. Chem., 2005, 48, 2093-2099.

14 S. Gómez-Ruiz, A. García-Peñas, S. Prashar, A. RodríguezDiéguez and E. Fischer-Fodor, Materials, 2018, 11, 224.

15 D. R. van Staveren and N. Metzler-Nolte, Chem. Rev., 2004, 104, 5931-5986.

16 D. E. Bean, P. W. Fowler and M. J. Morris, J. Organomet. Chem., 2011, 696, 2093-2100.

17 H. Fliegl, S. Taubert, O. Lehtonen and D. Sundholm, Phys. Chem. Chem. Phys., 2011, 13, 20500-20518.

18 M. D. Rausch, Can. J. Chem., 1963, 41, 1289-1314.

19 K. Heinze and H. Lang, Organometallics, 2013, 32, 5623-5625.

20 D. Astruc, Eur. J. Inorg. Chem., 2017, 6-29.

21 A. Pal, S. Ranjan Bhatta and A. Thakur, Coord. Chem. Rev., 2021, 431, 213685.

22 I. Simkowa, L. Latos-Grażyński and M. Stępień, Angew. Chem., Int. Ed., 2010, 49, 7665-7669.

23 I. Simkowa, L. Latos-Grażyński and M. Stępień, Angew. Chem., Int. Ed., 2013, 52, 1044-1048.
24 L.-L. Li and E. W.-G. Diau, Chem. Soc. Rev., 2013, 42, 291-304.

25 A. P. Castano, T. N. Demidova and M. R. Hamblin, Photodiagn. Photodyn. Ther., 2004, 1, 279-293.

26 M. Ethirajan, Y. Chen, P. Joshi and R. K. Pandey, Chem. Soc. Rev., 2011, 40, 340-362.

27 M. Jurow, A. E. Schuckman, J. D. Batteas and C. M. Draina, Coord. Chem. Rev., 2010, 254, 2297-2310.

28 J. C. Barona-Castaño, C. C. Carmona-Vargas, T. J. Brocksom and K. T. de Oliveira, Molecules, 2016, 21, 310.

29 G. Li, A. K. Dilger, P. T. Cheng, W. R. Ewing and J. T. Groves, Angew. Chem., Int. Ed., 2017, 57, 1251-1255.

30 T. Woller, P. Geerlings, F. D. Proft, B. Champagne and M. Alonso, J. Phys. Chem., 2019, 123, 7318-7335.

31 Z. S. Yoon, D.-G. Cho, K. S. Kim, J. L. Sessler and D. Kim, J. Am. Chem. Soc., 2008, 130, 6930-6931.

32 J. M. Lim, Z. S. Yoon, K. S. Kim, M.-C. Yoon and D. Kim, Chem. Commun., 2009, 261-273.

33 D. Sundholm, H. Fliegl and R. Berger, Wiley Interdiscip. Rev.: Comput. Mol. Sci., 2016, 6, 639-678.

34 H. Fliegl, S. Taubert, O. Lehtonen and D. Sundholm, Phys. Chem. Chem. Phys., 2011, 13, 20500-20518.

35 J. Jusélius, D. Sundholm and J. Gauss, J. Chem. Phys., 2004, 121, 3952-3963.

36 S. Taubert, D. Sundholm and J. Jusélius, J. Chem. Phys., 2011, 134(054123), 1-12.

37 A. D. Becke, J. Chem. Phys., 1993, 98, 5648-5652.

38 C. Lee, W. Yang and R. G. Parr, Phys. Rev. B: Condens. Matter Mater. Phys., 1988, 37, 785-789.

39 F. Weigend and R. Ahlrichs, Phys. Chem. Chem. Phys., 2005, 7, 3297-3305.

40 M. J. Frisch, G. W. Trucks, H. B. Schlegel, G. E. Scuseria, M. A. Robb, J. R. Cheeseman, V. G. Zakrzewski, J. A. Montgomery Jr, R. E. Stratmann, J. C. Burant, S. Dapprich, J. M. Millam, A. D. Daniels, K. N. Kudin, M. C. Strain, O. Farkas, J. Tomasi, V. Barone, M. Cossi, R. Cammi, B. Mennucci, C. Pomelli, C. Adamo, S. Clifford, J. Ochterski, G. A. Petersson, P. Y. Ayala, Q. Cui, K. Morokuma, D. K. Malick, A. D. Rabuck, K. Raghavachari, J. B. Foresman, J. Cioslowski, J. V. Ortiz, A. G. Baboul, B. B. Stefanov, G. Liu, A. Liashenko, P. Piskorz, I. Komaromi, R. Gomperts, R. L. Martin, D. J. Fox, T. Keith, M. A. Al-Laham, C. Y. Peng, A. Nanayakkara, C. Gonzalez, M. Challacombe, P. M. W. Gill, B. Johnson, W. Chen, M. W. Wong, J. L. Andres, C. Gonzalez, M. Head-Gordon, E. S. Replogle and J. A. Pople, Gaussian 16, Revision A.02, Gaussian, Inc., Pittsburgh, PA, 2016.

41 M. Rauhalahti, S. Taubert, D. Sundholm and V. Liegeois, Phys. Chem. Chem. Phys., 2017, 19, 7124-7131.

42 R. R. Valiev, H. Fliegl and D. Sundholm, Chem. Commun., 2017, 53, 9866-9869.

43 R. R. Valiev, H. Fliegl and D. Sundholm, Phys. Chem. Chem. Phys., 2017, 19, 25979-25988.

44 R. R. Valiev, G. V. Baryshnikov and D. Sundholm, Phys. Chem. Chem. Phys., 2018, 20, 30239-30246.

45 R. R. Valiev, I. Benkyi, Y. V. Konyshev, H. Fliegl and D. Sundholm, J. Phys. Chem. A, 2018, 122, 4756-4767.

46 E. Hückel, Z. Phys., 1931, 70, 204-286. 
47 E. Hückel, Z. Phys., 1931, 72, 310-337.

48 R. Breslow, Acc. Chem. Res., 1973, 6, 393-398.

49 N. C. Baird, J. Am. Chem. Soc., 1972, 94, 4941-4948.

50 K. Jorner, B. O. Jahn, P. Bultinck and H. Ottosson, Chem. Sci., 2018, 9, 3165-3176.

51 H. Fliegl, D. Sundholm, S. Taubert, J. Jusélius and W. Klopper, J. Phys. Chem. A, 2009, 113, 8668-8676.

52 M. Rosenberg, C. Dahlstrand, K. Kilså and H. Ottosson, Chem. Rev., 2014, 114, 5379-5425.

53 J. Ahrens, B. Geveci and C. Law, Visualization Handbook, Elsevier, 2005, ISBN-13: 978-0123875822, see also http:// www.paraview.org.
54 J. Weber, A. Goursot, E. Penigault, J. H. Ammeter and J. Bachmann, J. Am. Chem. Soc., 1982, 104, 1491-1506.

55 S. Y. Ketkov, S.-Y. Tzeng, E. A. Rychagova, G. Markin, S. Makarov and W.-B. Tzeng, Dalton Trans., 2021, 50, 10729-10736.

56 B. Rudshteyn, J. Weber, D. Coskun, P. A. Devlaminck, S. Zhang, D. R. Reichman, J. Shee and R. Friesner, ChemRxiv, 2021, DOI: 10.26434/chemrxiv.14751684.v1.

57 C. Cauletti, J. C. Green, M. R. Kelly, P. Powell, J. van Tilborg, J. Robbins and J. Smart, J. Electron Spectrosc. Relat. Phenom., 1980, 19, 327-353.

58 J. C. Green, Struct. Bonding, 1986, 43, 37-112. 